decrease of nearly 67 million barrels, or 5 per cent, of the total recorded for the previous year. The analysis of production by countries is interesting. For example, in 1930 the second largost producer was Venezuela, while in 1931 Russia camo second on the list, the United States taking as hitherto prior place. In 1932 the production of Venezuela still further decreased, Russia again taking sccond place to the United States, the total output of which was 781 million barrels, or about 60 per cent of the world's total. Of the British Empire resourees, Trinidad is tenth on the list with a production of 10 million barrels. British India was responsible for 8 million barrels; Sarawak for a little more than 2 million barrels; Fgypt for $1 \frac{3}{4}$ million barrols; Canada for I million barrels, a noteworthy decline. Tho output of oil from Persia showed an increaso over the previous two years with a total of $\mathbf{4 9}$ million barrels, while that from Iraq remained much the same at a littlo loss than 1 million barrels. It is probably safe to say that the general decrease in production for the year of some 67 million barrels is due rather to such measures of conservation as may have been satisfactorily adopted and also to general marketing conditions, rather than to any noteworthy decline in the actual natural resources of petroleum.

\section{Forecasting Rainfall in Queensland}

Many parts of Australia lie on the marginal zone in which the rainfall is sufficient in good yeurs but in bad years drops below the level required to maintain the pastures. Disastrous droughts have occurred from time to time in the past, and may be expected to recur in the future, but hitherto no satisfactory method of forecasting them has been found. $\mathrm{Mr}$. Inigo Jones, director of the Bureau of Scasonal Forecasting in Brisbane, has been investiguting the problem, and as a basis for study, he has collected all the available long records of rainfall in Queensland, including 159 stations, which he has published in tho form of monthly tables. Tho lines on which $\mathrm{Mr}$. Inigo Jones is attacking the problem of foretelling these droughts are set out in another pamphlet, entitled "Seasonal forecasting" (Brisbane, 1932). He believes that the weather of Australia is dominated by solar influences, but that these cannot be expressed simply and directly by the sunspot curve. In some way the solar activity is governed by the revolutions of the planets, resulting in a multiplicity of cycles, but the author's ideas on the subject are vague. This would not matter so much if the meteorological data were handled scientifically, but ho proceeds to "prove" this hypothesis by picking out the occasions on which the facts agree, more or less, with the theory. Perhaps a more thorough test is now in progress, based on tho extensive rainfall data for Queensland referred to above. It may bo remarked that one result of the planetary hypothesis is that the main sunspot cyclo should be the period of Jupiter, 11.86 years, but the meteorological evidence is almost wholly in favour of the shorter cycle of just ovor 11 years, as shown, for example, in the fluctuations of level of Lake George in Australia (Nature, 112, 918, Dec. 22, 1923).

\section{The Collecting Net}

THE Collecting Net is a flourishing weekly publication belonging exclusively to tho biological institutions of Woods Hole. Nos. 1 and 2 of vol. 8 (July 1 and 8,1933 ) are now before us. The purpose of the journal is to assemble material of spocial interest to workers in the Marine Biological Laboratory, the Woods Holo Oceanographic Institution and the United States Bureau of Fisheries. The editorial contents are divided into four parts : results of the scientific work reported during the summer of Woods Hole; items reporting the activities of members of the scientific institution of Woods Holo; world. wide news of the activities of institutions and individuals working in the field of biology ; the more important local news. There is a directory for 1933 containing the names and addresses of investigators in the laboratories beside short articles on various researches and apparatus and laboratory notes. Interesting accounts of the Scripps Institution of Oceanography and of the Biological Laboratory of Cold Spring Harbor are written by thoir respective directors, Dr. Thomas Wayland Vaughan and Dr. Reginald G. Harris. The annual subscription is only two dollars and the magazine is well printed and illustrated.

\section{Marine Studies in South Africa}

REPORTS 8 and 9 of the Marine and Biological Survey of the Union of South Africa for 1929-31 include two special reports as well as a large collection of important fishery statistics. The latter is the result of extensive investigation over the 2,500 miles of coast from St. Lucia Bay to Walvis Bay. In a valuable paper on the "Post-Brephalus Development of South African Macrura", W. von Bonde describes the various phyllosoma and puerulus larvæ of the Palinuridæ, Panuliridæ, and Scyllaridæ of this region. The work is well illustrated, and contains interesting notes on the development of the nervous system. It is unfortunate that the method of describing larva from the plankton samples does not permit of identification of species. Much experimental work on these lines remains to be done. In tho second paper, on "Hydrographical Investigations in South African Seas", J. M. Marchand makes a survey of the variation in temperature and salinity throughout the years 1929-31. He notes the effect of the Mosambique and Benguela currents on the coast of the sub. continent, but it is naturally impossiblo at present to make more than very broad genoralisations when working over such a largo area.

\section{Marine Biological Station at Ghardaga}

THE faculty of science of the Egyptian University has issued a report in English for 1931-32 containing a description of researches by members of the staff and a somewhat detailed account of the marine biological station at Ghardaga, which is situated on the edge of a group of extensive coral reefs. Corals of hundreds of different species, especially Madreporaria and Alcyonaria, cover the edges of most of the reefs to a depth of 5-6 fathoms and are in such 